How to cite this work: Moore-Cherry, N. (2020). Urban redevelopment, governance and vulnerability: thirty years of 'regeneration' in Dublin. Boletín de la Asociación de Geógrafos Españoles, (87). https://doi.org/10.21138/bage.3004

\title{
Urban redevelopment,
}

\section{governance and vulnerability: \\ thirty years of 'regeneration' in Dublin}

\author{
Reurbanización urbana, gobernanza y vulnerabilidad: \\ treinta años de "regeneración" en Dublín
}

\author{
Niamh Moore-Cherry \\ niamh.moore@ucd.ie \\ School of Geography \\ University College Dublin (Ireland)
}

\begin{abstract}
Over the last three decades, state intervention through urban regeneration has focused on 'fixing' perceived social and spatial vulnerabilities within particular neighbourhoods, communities or city spaces but has often generated new urban crises. Previous research examining regeneration over significant periods of time in the UK and Ireland, suggests that often the same spaces and communities are subject to repeated rounds of intervention. In this paper, the thirty year trajectory of regeneration in Dublin Docklands is examined. The importance of global flows of capital and how they are mediated by local contexts, actors and institutions through roll-back, roll-out and rollwith-it forms of neoliberalisation are examined. Since the global financial crisis, neoliberal governmentalities have been more deeply embedded in place through new institutions and the formation of a new growth machine that has produced new vulnerabilities. Dublin Docklands has been successfully commodified and marketized through the sustenance, albeit changing, of a growth logic over more than 30 years. Yet significant challenges related to governance, social
\end{abstract}


inclusion and spatial justice remain, and arguably have been (un-) intentionally co-produced in new forms by sustained rounds of state intervention.

Key words: urban regeneration; governance; neoliberal cities; entrepreneurial urban governance; vulnerability.

\section{Resumen}

Durante las últimas tres décadas, la intervención estatal a través de la regeneración urbana se ha centrado en "arreglar" las vulnerabilidades sociales y espaciales percibidas dentro de vecindarios, comunidades o espacios urbanos particulares, pero a menudo ha generado nuevas crisis urbanas. Investigaciones anteriores que examinan la regeneración durante períodos de tiempo significativos en el Reino Unido e Irlanda, sugieren que a menudo los mismos espacios y comunidades están sujetos a repetidas rondas de intervención. En este artículo, se examina la trayectoria de treinta años de regeneración en Dublin Docklands y la importancia de los flujos globales de capital y cómo son mediados por contextos, actores e instituciones locales a través de la reversión, la implementación y la implementación, así como las formas de neoliberalización. Desde la crisis financiera global, las gubernamentaciones neoliberales se han arraigado más profundamente a través de nuevas instituciones y la formación de una nueva máquina de crecimiento que ha producido nuevas vulnerabilidades. Dublin Docklands se ha mercantilizado y comercializado con éxito gracias al sustento, aunque cambiante, de una lógica de crecimiento durante más de 30 años. Sin embargo, persisten desafíos importantes relacionados con la gobernanza, la inclusión social y la justicia espacial, y posiblemente se hayan coproducido (no) intencionalmente en nuevas formas mediante rondas continuas de intervención estatal.

Palabras clave: regeneración urbana; gobernanza; ciudades neoliberales; gobernanza urbana empresarial; vulnerabilidad.

\section{Introduction}

The role of the state in urban redevelopment and regeneration has been a pre-occupation in urban studies for a significant length of time, shifting from an emphasis on examining consequences of the 'rolling back' of the state in the 1980s to the 'rolling-out' of new interventions in the early years of this millennium and the emergence of 'roll-with-it' neoliberalism (Keil, 2009), and more recently on the state role in austerity and financialised urbanism (Peck, 
2012; O'Brien et al., 2019; Aalbers, 2020). Although regeneration is positioned as a product of de-regulation and liberalization, the reality is that, in many if not all cases, it has required more not less state intervention (Ward, 2003), often-times repeatedly in the same geographical areas (Henderson, 2012; Moore-Cherry, 2015). While the scope and focus of regeneration activities have shifted in line with broader political-economic and ideological shifts in terms of how to do governance 'best', the state has remained a ubiquitous and amorphous presence in the urban environment. As well as an actor in its own right, the state often acts as broker or mediator between other actors. The persistent nature of, and tinkering with, state intervention has been characterized as a 'crisis of crisis management' (Jones and Ward, 2002). As state actors intervene to address one particular issue such as a deteriorating physical and economic environment, the outcomes of intervention create new problematics through processes such as gentrification, over-heated housing markets and social exclusion. One strategy of addressing these crises has been for the state to insert itself as a 'macro-actor' bringing a range of different groups together, shaping a 'network politics', and playing a crucial role in supporting urban regimes (Ponzini \& Rossi, 2010) and often-times playing particular brokering roles within urban growth-machines (Molotch, 1976). Rather than being directly involved in decision-making, the state begins to operate within a meta-governance framework laying the ground rules and providing general oversight or coordination of other actors (Brenner 2004; Painter \& Jeffrey 2009). In the period since the 2008 Global Financial Crisis, the context has shifted considerably yet rather than neoliberal urbanism being questioned and challenged, more and new intervention by the state and its agencies has deepened governmentalities normalizing growth-first or competitive logics. Drawing on Jessop's (1990) conceptualisation of the state as a loose set of institutions, this paper focuses on the experience in Dublin (Ireland) and particularly of its largest regeneration project, the Dublin Docklands regeneration.

This part of Dublin has been subject to repeated interventions by a variety of state actors for more than thirty years. The physical and socio-economic character of the area, like in many other waterfront cities, was a product of port retreat, which although evident from the nineteenth century, accelerated rapidly in the 1960s and 1970s. Across similar cities in Europe and North America at the time, the abandonment of older dock areas combined with economic recession in the late 1970s and 1980s to result in physical degeneration and the emergence of complex and intertwined social, economic and physical problems. The devastating impact of late twentieth century technological and economic change on Dublin docklands was exacerbated by the traditional physical and socio-economic character of the area, which was one of comparative 
disadvantage and relative weakness. These urban weaknesses or vulnerability were structural and institutional, but their interplay with more intense state intervention has generated significant complexity.

The paper adopts an intensive qualitative case study methodology based on a review of secondary materials including newspaper reports, official government reviews and reports, marketing materials, press releases and other texts to illustrate the relationship between shifting forms of state intervention and changing patterns of vulnerability. It is a story of some continuity but significant change. It draws on a desk-based study of longer term plans and policies for the area combined with a series of interviews undertaken over the last twenty years on related projects (Moore, 1999; 2002; 2008; Moore \& Vinci, 2012; Moore-Cherry et al., 2015) to investigate the practice of regeneration, its dynamics and consequences.

\section{The urban state}

Since the late 1980s, state intervention in the urban landscape has been characterised by an entrepreneurialism linked to broader processes of neoliberalisation. Based on a combination of competitive and network-building tendencies, Jessop (1997, 1998) has argued that entrepreneurial urban governance (EUG) is defined in particular by the emergence of networks of unelected decision-makers operating in a manner that circumvents formal decision-making and in particular, the decision-making channels of local government. The creation of state agencies bridging the traditional public-private divide has been a feature of contemporary urban governance and the vehicle through which new power and activity networks have been created and sustained. Couched within the discourse of competitiveness, policymakers have argued that the ability of particular cities to "compete with other places in neo-liberal inter-urban competition is strengthened" (Jones \& Ward, 2002) through these new institutional arrangements. New state actors have been key players in not only revitalising but also economically revalorising urban spaces (Swyngedouw et al., 2002) as they coordinate or incentivize other actors to come together in the pursuit of mutually beneficial growth, often packaged as in the public interest. Fuller and Geddes (2008) argue that in the rolling out of these new state forms, and through such growth machine dynamics, a blurring of the distinction between public and private in certain policy realms has occurred with mixed effect.

Underpinning the arguments of those advocating new institutional structures and governance reform has been the construction of the state as a rigid monolith stifling progress and innovation. More 'stream-lined' decision-making delivering greater efficiency and demonstrating flexibility, 
would fulfill the desire for a more solutions-based or problem-oriented approach. The argument suggests that these attributes could only be found through greater engagement with the private sector or some new state actor operating according to private sector norms. Ward (2007) has described this as a 'post-political' urban condition whereby a consensus around the inevitability of neoliberal capitalism has emerged, legitimising certain policies, practices and institutional forms. Keil (2009 suggests that this new phase of 'roll-with-it neoliberalism' has emerged as particular governmentalities of intra-urban competition, growth and global cityness have become normalized, driving and justifying particular actions. Very often, issues of sustainability, resilience, local identity, equity and liveability have become secondary. Questions of the city for whom and in whose interests the state is operating under these chameleon-like neoliberalised urban conditions loom large.

One line of enquiry is whether entrepreneurial urban governance has really delivered a more stream-lined and effective urban policy environment? As 'actually existing neoliberalism' demonstrates a policy thickness hitherto unknown (Brenner \& Theodore, 2005), the evidence would suggest the contrary. In his work on Wolverhampton, Henderson $(2012$, p. 1) illustrates the diversity and layering of regeneration interventions that have occurred in that city over twenty years yet concludes that finding 'the most effective governance structures to facilitate urban regeneration remains an ongoing challenge'. These kinds of repeated interventions point to patterns of state disconnect rather than state efficacy: the first disconnect is linked to how various policy initiatives link together spatially and their cumulative impacts on already vulnerable neighbourhoods; the second relates to an institutional disconnect between different traditional and new state actors in the urban policy and regeneration domain particularly in a multi-level governance framework (Moore-Cherry et al., 2015). Although some literature suggests that the state now operates as a 'macro-actor' brokering new sets of relationships through the practice of regeneration and network politics (Ponzini \& Rossi, 2010), other experiences would suggest that it has become more involved in micro-scale activity creating institutional complexity rather than streamlining and working to sustain a political-economy based on expansive capitalism.

A second line of enquiry is the relationship between new 'entrepreneurial' state agencies and other actors. Substantial discussion has already taken place on the negative central-local government relationship that emerged as a consequence of the rolling-back of local authority power and establishment of new development agencies in particular urban areas in the late 1980s and 1990s (Smith, 1990; Tewdwr-Jones, 2012). The sustained undermining and exclusion of local government from early regeneration initiatives was justified through the discourses of 
inefficiency, inflexibility and bureaucracy noted above, and placed in direct contrast to the dynamic and apparently go-getting character of new development agencies (Brownill, 1990; Thornley, 1991), for example the London Docklands Development Corporation, that exemplified a re-centralisation of state activity and power. The resultant central-local government tensions stood in direct contrast to the portrayal of positive and productive working relations between the state (in the form of new development agencies) and the private sector in the pursuit of mutual goals (Lowndes et al., 1997; Osborne, 2002). While new state bodies set up to deliver regeneration may have challenged inherited institutional arrangements, "the most important of which is local government" (Fuller and Geddes, 2008, p. 252), the consequences of their activity including the blurring of the public-private distinction, have demanded greater intervention than ever before challenging the simplistic idea of the state as exclusively a 'macro-actor'. Resolving the contradictions generated by this fuzziness has generated significant questions regarding the operation of 'network politics' in the city and the role of government within governance networks (Davies, 2002).

Drawing on the empirical evidence from Dublin Docklands, this paper questions the efficacy and productivity of the new urban politics, highlighting how the 'state' has been differentially appropriated over time for different ends, generating new and variegated vulnerabilities in the process. The state co-produces vulnerabilities often as an (un-)intended consequence of earlier rounds of intervention to mitigate weaknesses, as evident in the economic, property and legitimacy crises of the 2008 global financial crisis and its aftermath. Despite the possibilities provided by the post-crash context to re-configure planners, planning and other actors in a new urban context and to move institutional fixations with urban development beyond bricks, mortar and circuits of global capital (Moore-Cherry, 2015), post-crisis urbanism has evolved from an earlier form of 'roll-with-it neoliberalism' within an environment where 'entrepreneurialism', growth and competition remain the dominant motifs (Brownill \& Carpenter, 2009; Cox, 2010), where the urban land market, housing and infrastructure is increasingly financialized (O'Callaghan et al., 2015; Aalbers, 2020) and where urban inequalities persist. It may be that the politics of urgency, the need to be seen to do something in a single crisis or recurrent crises, mitigates against new thinking, and sustains the status quo. Moving towards a governance of preparedness (Medd \& Marvin, 2005) based on holistic, anticipatory and longer-term thinking, requires understanding the structural production of urban vulnerabilities under late capitalism and in particular how the relationship of particular communities with, and within, the city is mediated and shaped by institutions, socio-economic structures, and cultural values. The next section 
introduces the case study highlighting how successive regeneration plans and programmes have been motivated by the resolution of particular weaknesses -initially physical and sociodemographic but later institutional and financial- with varying degrees of risk and success.

\subsection{The context: Dublin}

Dublin City in Ireland has been subject to intense transformation since the mid-1980s. In line with many other cities across Europe and North America in particular, the physical and social fabric of the inner city was torn apart due to lack of private investment, fiscal crisis in the local authority and a long economic recession. The new towns approach and policies of decentralisation that had characterised urban policy in the 1960 boom years was a key contributor to the neglect of the inner city and by the late 1970s, there was growing acceptance of the need for policy change to halt decay. An unprecedented rise in unemployment between 1971 and 1981, a result of global recession following successive 'oil crises', affected inner city Dublin particularly badly. The fragility of indigenous industry and dependence of the Irish economy on foreign enterprise resulted in disproportionate negative repercussions of global economic change. In addition, membership of the EEC (from 1974) had resulted in the closure of many inefficient labourintensive indigenous industries. Standardisation of industrial practice across Europe also threatened Ireland's export trade to UK markets. A review of industrial policy carried out in the early 1980s advocated for the promotion of export oriented indigenous industry and co-operation between policymakers, large companies and financial institutions (Telesis Consultancy Group, 1982). It was within this changing economic and political environment that the government began to recognise the need to halt the physical impact of industrial decline in the urban core and restructure the economy, resulting in a series of policy suggestions culminating in the Urban Renewal Act in 1986.

Based on the approach elsewhere, the Urban Renewal Act (1986) was an area-based initiative $(\mathrm{ABI})$ targeting specific parts of the city centre for physical regeneration. Coupled with a low corporate tax regime, financial incentives and a flexible regulatory environment, it marked a concerted attempt by central government to directly intervene at the urban scale, by empowering the Minister of the Environment to designate specific areas for renewal. All areas benefited from a standard package of tax incentives provided in the 1987 Finance Act and extended in the 1995 Act with additional incentives for financial services activities targeted at a small waterfront area, the Custom House Docks Area. Initial perceived successes at 'rebooting the inner city' encouraged the expansion of the scheme, and by 1994 whole swathes of the city were subject to 
some form of tax incentive. In addition, special urban development agencies were established in the waterfront zone north of the river (Custom House Docks Development Authority) and in part of the historic core on the south side of the city (Temple Bar Properties). This type of interventionist, project-based approach was later expanded with the support of European funding to the historic markets area around Smithfield (HARP), which soon after informed a new approach - Integrated Area Planning (IAP) - across a large part of the city centre. Moore-Cherry et al. (2015) have outlined how the production of a mosaic of plans, policies and new institutions across the inner city created a specific geography of concentrated and overlapping intervention in two areas of the inner city (Figure 1), one in the historic markets and industrial spine of the city (marked area 1) and the second in the docklands area, the focus of this paper, on the eastern side of the city occupying land north and south of the river Liffey (marked area 2, Figure 1).

Figure 1. Composite map of state interventions in Dublin inner city

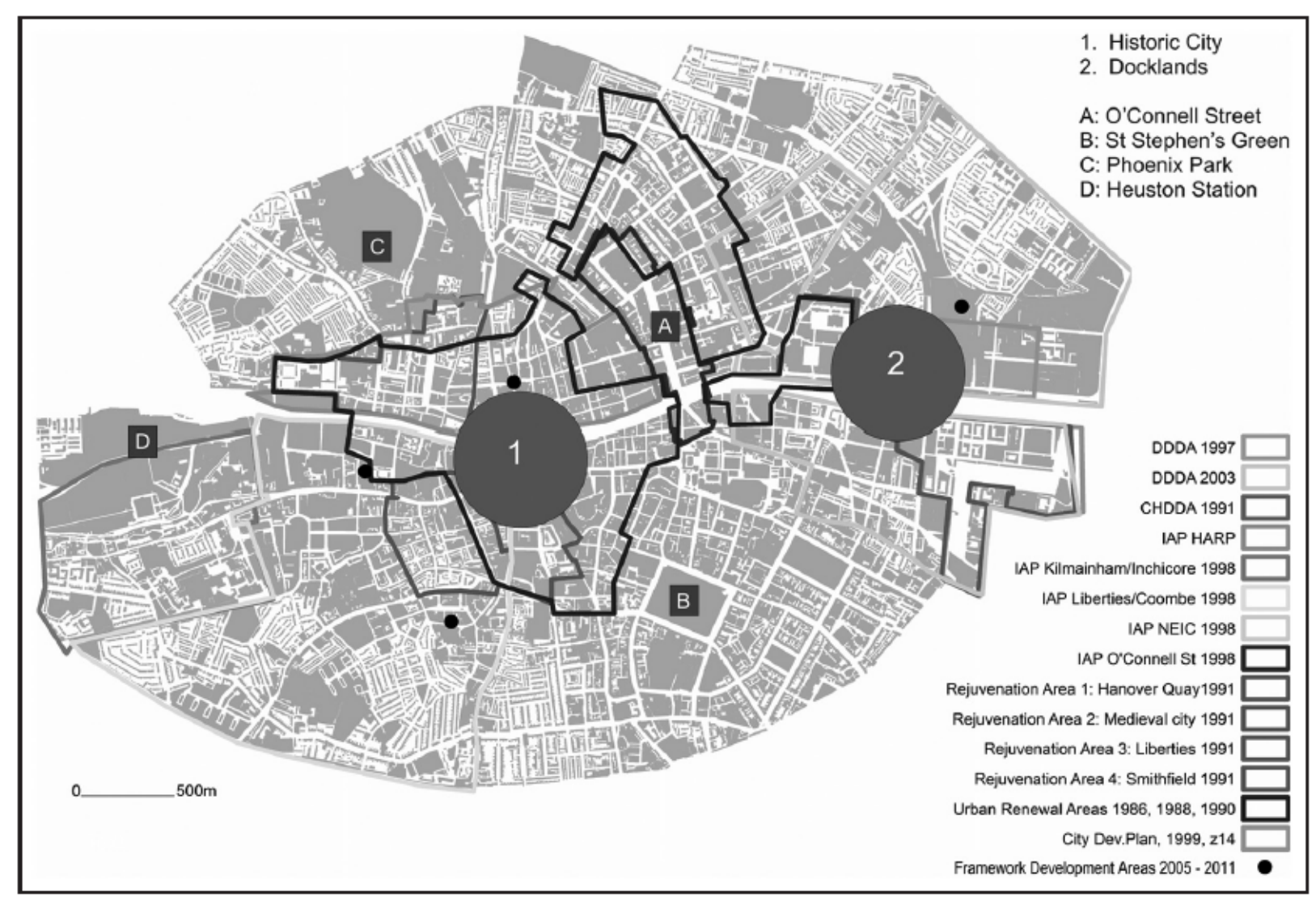

Source: Moore-Cherry et al. (2015)

\section{Dublin Docklands as Case Study}

The history of the Dublin Docklands can be read as a microcosm of the history of Ireland, both ancient and modern. The making of the Docklands itself is a complex 
tapestry of great engineering achievement, visionary planning, intrigue, economic rise and decline, and human triumph over adversity (DDDA, 1997, p. 18).

Since the late 1980s, the transformation of the Dublin Docklands has been dramatic and it ranks as one of the largest-scale regeneration projects ever undertaken in Ireland and Europe. Similar to many waterfront districts in Europe and North America, the advent of containerisation and the need for new terminals to accommodate growing ship-sizes, resulted in a shift in the location of the working port to a more spacious and deeper-water zone. The immediate impact was the emergence of an interstitial district between port and city physically characterised by empty warehouses, large and under-utilised water bodies and abandoned railyards and socially isolated from the city core. Drawing on the international experience and particularly influenced by the contemporaneous developments in London Docklands and Liverpool's Merseyside, a small part of the former port (27 acres) was targeted by the government in 1987 for regeneration and a new development agency -the Custom House Docks Development Authority (CHDDA) - was established. Since that time, the area has gone through dramatic change -physically, economically, socially and in terms of its economic positioning within the city, nationally and internationally. Dublin docklands is a peculiar exemplar of the relationship between vulnerabilities and opportunities in the urban context and their relationship to the governance of regeneration. Temporally, three distinct phases are evident in the historical evolution of the district, each arguably emerging in response to crisis or shock and linked to the vulnerability of the district to global circuits of capital. These are:

- Deepening global interconnectedness and growing neighbourhood inequalities: 1987-1997

- 'Fixing' global capital flows and intensifying precarity: 1997-2008

- Global collapse and institutional vulnerabilities: 2008-2016

\subsection{Deepening global interconnectedness and growing neighbourhood inequalities (1987-1997)}

As with many waterfront cities during the latter half of the $20^{\text {th }}$ century, global economic restructuring and new technologies resulted in the redundancy of much of the former port area in Dublin. Dublin, and other Irish urban areas, were so adversely affected by this shift because of the dependence of the economy on specific kinds of enterprise (Telesis, 1982). How government would, or could, respond became an increasingly difficult question as the needs of local urban communities seemed to run at odds to what was emerging as best international practice for promoting economic growth. 
With the establishment of the Custom House Docks Development Authority (CHDDA) to oversee development in partnership with private interests, a new dawn emerged for urban governance in Ireland. The wisdom of using such a heavily streamlined development corporation was questioned at the time as it raised 'important questions as to the nature of the planning approach being used, the relationship to the surrounding local authority, Dublin Corporation, and most of all the relationship to the adjacent communities and their participation in or benefit from such an undertaking' (Bannon, 1989, p. 170). This single-minded development agency aspired to the amelioration of long term economic, physical and social problems, through the implementation of targeted regeneration strategies similar to those adopted by the London Docklands Development Corporation. The raison d'être was to rejuvenate this historically significant, yet decaying part of the urban core, in the national interest. The encouragement of local businesses and the opening up of Dublin to global flows would diversify employment opportunity within the city-region and mobilise local skills (Benson, 1988, p. 91). In an attempt to counter some of the emerging concerns about the likely trajectory of change, the CHDDA stated a clear intention in their initial Planning scheme (1997) to establish a consultative community liaison programme during the development phase and to provide financial assistance to local community groups. Yet, the community liaison committee $(\mathrm{CLC})$, comprising members of the authority and representatives of community groups, was not established until 1995.

The attraction of private investment into the docklands area was the critical issue facing the CHDDA and the flagship International Financial Services Centre (IFSC) was to attract mobile global capital to Dublin with the overall aim of improving tax revenue and jump-starting an ailing national economy. The attractiveness of the IFSC to overseas operators was dependent on a number of different aspects. Firstly, it was declared a tax haven, and thus could successfully compete with other offshore tax havens including the Isle of Man and the Channel Islands. Secondly, locating in Ireland would give access to European Union markets that these other tax havens could not. Thirdly, competitiveness with Luxembourg, also an EU member state and therefore attractive to investors, was assured through the provision of an exceptionally low corporation tax rate of 10 per cent. In essence, the role of the IFSC was to capture and reorient global flows of investment capital into Dublin and this could only be achieved through new combinations of global local, state and private actors, operating as an urban growth machine (Molotch, 1976). International investment capital was coupled with central government incentives, growing developer interest, and a boosterist promotion of Dublin as 'national champion' (Crouch \& Le Galès, 2012) by state agencies such as the Industrial Development Authority. The docklands 
were instrumentalised as a tool in projecting Ireland outwards and reasserting its position in the new world order and global economy.

Typical of its time, the core remit of the CHDDA was physical regeneration through an entrepreneurial approach to urban development designed at stimulating private sector development and this was part of a broader government strategy aimed at promoting growth. The establishment of the agency removed all local authority planning power from the area, justified through a discourse of streamlining, efficiency and ability to deliver, and was coupled with the establishment of a favourable tax regime by central government (Moore, 1999). In effect, the CHDDA was the tool through which a "rolling back" of the state - specifically the local authorityoccurred in the late 1980s. By the mid-1990s and perhaps linked to the 'turn to community' that was permeating much of British and Irish planning discourse (Duffy and Hutchinson, 1997), this approach began to be questioned. While the agency was an undoubted success in delivering on physical and economic regeneration (3,000 jobs in the international financial services sector had been created and over $€ 814$ million had been collected in corporate tax revenue), the social issues of unemployment, deprivation and poor educational outcomes, that had spurred the need for regeneration in the 1980 s remained unresolved.

In certain areas unemployment rates remained stubbornly high - estimates suggest that it was as high as $80 \%$ in Sherriff Street in the heart of docklands- while the remainder of the Irish economy benefitted from falling unemployment and increased prosperity. Rather than riding the back of the Celtic Tiger boom, some dockland residents described a sense of being mauled by it as social polarisation increased between longer-term communities and the new, mainly professional classes who wished to reside in this new urban quarter. Local residents and some politicians believed that within the sphere of influence of the CHDDA, nothing more than 'yuppy enclaves' were developed (Lambe, 1998; Gregory, 1998, personal communication).

A deepening but changed sense of vulnerability emerged within local communities as the local socio-environment radically changed alongside institutional, cultural and economic transformations. Just as the economy and physical landscape was being increasingly internationalised, local communities found themselves part of a global network of dockland communities put under tremendous pressure by redevelopment, and packaged as regeneration. As the project evolved a palpable change in mood by the local community from their initial optimism to a more confrontational approach became evident, epitomised in the words of Gerry Fay, local activist, who warned that: 
Maybe they thought when they started dealing with us that the community would be dislodged and moved on, but the reality is that we've fought hard to stay. People who are moved out of the Sheriff Street Flats are going to be re-housed nearby. The dock authority will ignore the local community at their peril. (The Irish Times, December, 29, 1989)

The regeneration undertaken by the CHDDA did not significantly improve the quality of life for long term residents of docklands, but it fundamentally altered the relationship between them and their immediate surroundings. The physical environment and services developed within the original IFSC site became increasingly alien to a community that required basic intervention across a range of social issues including education, employment and community-support infrastructure. For many, their new 'neighbours' became representative of, and were benefiting from, the products of global capital and conspicuous consumption that was beyond the reach of the majority, deepening the sense of isolation and abandonment. Although initially inspired by a desire to address the impacts of global economic restructuring on the former port area and its communities, the embedding of this area more deeply in global circuits of capital, exacerbated their marginalisation.

Following growing unease about the direction that the project was taking, a report was commissioned by central government in 1996 to benchmark the impacts of urban renewal policy generally and in the Custom House Docks in particular. It highlighted many limitations including the failure to develop the broad mixed-use development and heterogeneous social profile that was initially envisaged. The spin-off or 'trickle down' benefits promised in this new entrepreneurial approach to governance had failed to reach the most marginalized and vulnerable communities and demanded a new round and form of intervention to address growing inequalities.

\section{2 'Fixing' global capital flows and intensifying precarity (1997-2008)}

In the 1996 Budget statement delivered by the then Minister of Finance Ruairi Quinn, a public representative whose constituency included part of the south docklands, the intention of the government to redress the poor social outcomes of regeneration in docklands by adopting a more strategic and broad-ranging approach was announced. East of the Central Business District, a larger 526-hectare expanse, comprising one-tenth the size of the city between the two canals was designated as a new Dublin Docklands Area (DDA). Physically much of the area comprised wasteland and brownfield or old industrial sites, while in social terms, above-average 
concentrations of unemployment and other social problems still persisted despite a decade of 'regeneration' around the Custom House Docks.

Arguably, the decade from 1997 to 2007 can be characterised as a period when this district was being viewed relationally, in terms of how it was connecting to other places, but also territorially in terms of how global processes would be 'captured' and grounded in this particular district for wider benefit. A new set of planning ideas and governance framework was required to facilitate this revised version of 'actually existing neoliberalism' (Brenner \& Theodore, 2002). Ironically, at this point government tried to steer global capital and fix it in docklands through the construction of a new imaginary. While Dublin Port had a long history and cultural significance within the city, the idea of docklands was essentially a 'marketing tool' used to generate a particular form of place identity and attract investment but within a governance framework more directly focused on deriving social benefit. This 'turn to community' in planning was representative of what was happening more broadly in Europe at this time given the failure of the Thatcherite property-led approach to support local and disadvantaged communities. The new designated area encompassed strong and longstanding inner-urban communities with a powerful representative voice. As well as conceptualising Dublin Docklands as a test-bed for different and new forms of urban development, it increasingly became a part of the city where different cultures could be encountered and a place that facilitated flows of ideas, people and capital, but also captured those flows and grounded them in very particular ways.

In May 1997, the Dublin Docklands Development Authority (DDDA), subsuming all functions of the CHDDA, was established with an organizational structure designed to promote more democratic control and participation. The DDDA was to retain an 'entrepreneurial' spirit focused on pump-priming development and levering private sector investment with a target ratio of 4:1 but also increasingly operated in the role of 'macro-actor', brokering new relationships between a diversity of interest groups to neutralize or minimize potential conflicts. In effect, the Dublin Docklands Development Authority (DDDA) became crucial in the "rolling-out" of a revised form of neo-liberalism (Peck and Tickell, 2002) but with a veneer of social acceptability and concern:

We will develop Dublin Docklands into a world-class city quarter -one in which the whole community enjoys the highest standards of access to education, employment, housing and social amenity and which delivers a major contribution to the social and economic prosperity of Dublin and the whole of Ireland (DDDA, 2002). 
Due to the newfound emphasis on social and community goals within public policy, the growing polarization between the more established communities and new residents that had become apparent in the first decade of redevelopment, became a focus for attention. The governance structures of the new development authority included an Executive as well as a larger Council of key stakeholders, including very effective and vocal community representatives who wielded their influence to ensure that social infrastructure was prioritized, arguably a relatively easy win given the emerging context of an unprecedented economic boom from 2000-2007. Clearly apparent was the growing entrepreneurialism of community representatives to ensure that at least some of the benefits of fixing international investment capital in the area accrued to longer term residents. Part of the innovation ecosystem that emerged in Dublin Docklands related to new approaches to urban development, won through argument and negotiation by community interests during the production of the Master Plan for the district. Policies implemented elsewhere in Ireland during the late 1990s and early 2000a, such as the provision for a State-wide Affordable Housing Programme in the Local Government Planning and Development Act (2000), were first developed and implemented in the docklands driven by community demands for more direct, rather than 'trickle-down', community gain.

Following the establishment of the DDDA a comprehensive employment programme was enshrined in the Local Employment Charter stating that 20 per cent of new jobs in docklands should be offered to local residents first. This provision was a concession that local community representatives fought hard to obtain having initially been offered a 10\% quota in the draft 1997 Master Plan. The determination of community groups to ensure that benefits accrued to existing residents and that they were involved, if only in an advisory capacity, in determining the future shape of the area had much to do with their negative earlier experiences of regeneration. The most apparent change in this second phase of regeneration was the high level, interventionist approach of a variety of state agencies working in concert to address social need and the contribution of the local community to solving their own issues and shaping responses. Their earlier vulnerability became transformed into a motivator for demanding change, politicising and mobilising them in a more enabling institutional framework.

Although it seemed unlikely given the genesis of the wider docklands project in 1997, the experience of social regeneration in Dublin docklands was becoming an international model of good practice for other cities by 2007. The mistakes regarding lack of consultation and the primacy afforded to economic and physical development during the tenure of the CHDDA appeared to have been generally avoided. New social as well as flagship hard infrastructure - 
including the Beckett Bridge, Grand Canal Theatre, National College of Ireland, and Convention Centre Dublin - were seen as markers of success and this bred what might be described as an über-confidence, and possibly a recklessness, within the DDDA in terms of its own modus operandi. While the authority was effectively established as an arm of central government with direct accountability to the Minister for the Environment and Local Government, their emerging practices and activities suggested informal and internal institutional transformation creating a sense of 'ungovernability'. Jones and Evans (2006) have identified the co-existence of distance and proximity between the state and other actors as a critical feature of contemporary urban governance, but in Dublin this distance and proximity was clearly evident within the state, between its various arms. From its establishment in 1997 but most particularly from 2002 onwards, the operation and activities of the DDDA were heavily influenced by their inter-twined relationships with non-state actors, and in particular with the banking and development sectors. While the role initially envisaged for the DDDA may have been one of co-ordination and relationship-building as befits a 'macro-actor' (Ponzini \& Rossi, 2010), during the economic boom of the 2000's this shifted to such an extent that the agency became a development player in its own right generating significant vulnerabilities when the Great Financial Crisis hit Ireland in 2008.

\subsection{Global collapse and Institutional vulnerabilities (2008-2016)}

A watershed year for the global economic system, the year 2008 also marked the demise of what had been broadly heralded as the 'Celtic Tiger' economic miracle as a triple crisis (financial, fiscal and banking) took hold in Ireland. Through the early 2000's, much of the unparalleled 'growth' had been sustained by a speculative property bubble facilitated in part by generous mortgage relief (Kitchin et al., 2012). The easy availability of credit coupled with low interest rates and fiscal incentives for property development, that had long run their course, fuelled the construction boom. Whelan (2014) has calculated that "the total stock of mortgage loans in Ireland exploded from $€ 16$ billion in 2003:Q1 to a peak of $€ 106$ billion in 2008:Q3, about 60 percent of that year's GDP". A growing dependence on consumption-based taxes, became apparent with property-based taxes accounting for $20 \%$ of all Irish tax revenue in 2006 . By the late 2000's, property supply 'overshot' what was required, the market stagnated, and credit was closed off as the global financial crisis tool hold. Rather than relying on deposits, banks had engaged in high-risk practices borrowing short from the international money markets to lend to long-term projects, leaving the sector heavily exposed. In response in September 2008, the Irish government issued a blanket guarantee of the Irish domestic banking system in an effort to stem 
the withdrawal of large deposits and help facilitate capital raising. In early 2009, the most aggressive bank within the Irish banking sector, Anglo-lrish Bank, was nationalised and three other banks recapitalised. Given the scale of construction that had been ongoing in Dublin Docklands, the continued development of the area became threatened as the scale of bank exposure became clear. Major 'trophy' projects such as a new headquarter building for AngloIrish bank in the heart of the north docklands came to a standstill (Figure 2). It remained unfinished for over 6 years and became a symbol of all that had gone wrong with the Irish development model. In an effort to address the uncertainty regarding the banks' exposure to property related loans, and facilitate the recovery of the sector, Government announced the establishment of the National Asset Management Agency (NAMA) in an emergency budget in April 2009. NAMA is an asset resolution initiative, and effectively operated as a bad bank, to tackle the calamitous crisis in the Irish banking system. With the NAMA Act passed in November, it officially commenced operation in December 2009 and began the process of transferring property loans from five main banks. When these loans were assessed, it became clear that a significant number of development sites and properties within docklands were being held as security against them. With the passing of the Act, NAMA had suddenly and possibly unknowingly, become the key state player within the docklands district. This has had significant implications in the last five years in particular, as discussed in a later section.

As NAMA was entering the governance arena, concerns were growing within government and regulatory circles about how docklands had become so exposed, the role of the Docklands Authority, and its relationship to bankers and developers. Member of the Board of the Dublin Docklands Authority, were also key development players within the area and the Authority itself had engaged in risky development practices across a number of development sites. By June 2012, following three reports into the operation of the Authority and a damning indictment of its operation by the Comptroller and Auditor General, the Minister announced the winding down of the agency. All of the reports drew attention to the consequences of excessive blurring of the public-private divide within its operations and recommended the need for re-regulation with significant consequences for the role of the state, and more specifically the local authority, in this part of the city. While the modus operandi of the DDDA from its establishment in 1997 were framed and justified as the most appropriate way to harness global investment in the interests of creating a 'world-class' city quarter, the practice of regeneration illustrated more local and indeed individual motivations shaping the practice of regeneration under this globalist guise. The 'growth-machine' driven by a few key actors in powerful positions became so 'hyper- 
entrepreneurial' that it ultimately undermined the drive for more urban growth, leaving the area completely exposed to the vagaries of the global economy, and the collapse of the banking and development sectors. The way in which a particular growth machine was constituted and the vulnerabilities it generated are illustrated by the story of one project, the Irish Glass Bottle site.

Figure 2. Stalled development at the Anglo-Irish bank headqaurter building

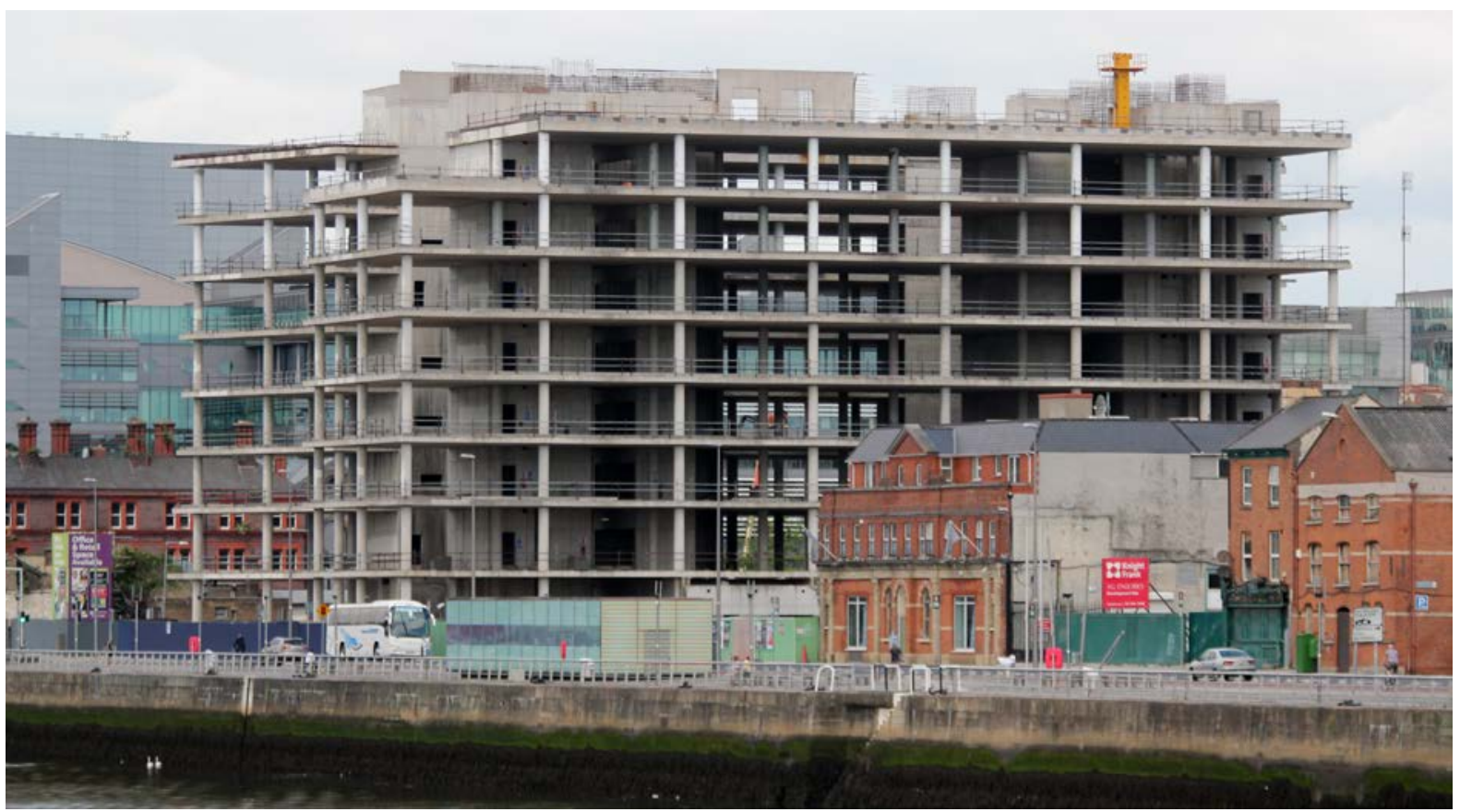

Source: author's own elaboration

\section{a) Example: Irish Glass Bottle site}

This 24-acre site, located in the south docklands, had been owned for many decades by Dublin Port Company (a semi-state agency) and leased for manufacturing and warehousing purposes to the former Irish Glass Bottle company. On the back of the booming property market within the adjacent docklands, the owners sold the site in 2006 for $€ 412$ million to the Becbay consortium. This group comprised a developer Bernard McNamara (41\%), property financier Derek Quinlan (33\%) and, to the surprise of many, the Dublin Docklands Development Authority (DDDA) (26\%) all focused on maximizing economic returns from this former port site. Dublin Port Company received $€ 138$ million following the closure of the transaction, representing a transfer of state monies from one institution (DDDA) to another, Dublin Port Company. Following the property crash in 2008, the site was re-valued at approximately $€ 45$ million, just $11 \%$ of what had been paid. The implications of this collapse in value were financially significant, but also highlighted how the politics of place was centred on the commodification of this marginal urban location through sophisticated marketing activities, and was enabled through the blurring of state 
responsibilities and roles in this area, and poor regulation, ultimately producing not just an economic or property but also a governance crisis.

As Fuller and Geddes (2008, p. 256) explain roll-out neoliberalism is about "managing the socio-spatial contradictions and tensions that have arisen from and been exacerbated by neoliberal accumulation processes and the state strategies of the preceding period". However, the case of the Irish Glass Bottle site, illustrates that state responses and interventions were shaped by discourses of autonomy, flexibility and innovation in a form of not just 'roll-back' or 'roll-out', but also 'roll-with-it' neoliberalism producing deeper difficulties and vulnerabilities as these discourses became increasingly normalised. As Keil (2009, p. 232) observes "actors moving along their various registers create new contradictions, struggles, conflicts and possibilities" and these were adversely compounded by the exposure to external shock.

With regard to the specific case of the Irish Glass Bottle Company (IGB) site, this was part of a broader area known as the Poolbeg Peninsula on which the local authority, Dublin City Council (DCC), was the key planning authority. In October 2003, a draft framework plan was commissioned as part of a marketing of the area as 'Dublin South Bank'. The plan identified the district as the potential home for 18,000 people -in the context of tight land supply more generally within the city- but issues including traffic and transport management, soil contamination and other infrastructural issues were not considered in detail. Nearby residents and local political representatives claimed that this proposal disregarded the Master Plan for the entire docklands area produced by the DDDA, which recommended a Section 25 fast track planning status for the IGB site and its environs. This would have effectively removed the site from the traditional planning channels - and power of the city council- and given the docklands Authority planning permission for any development that was in line with a general planning scheme for the site. The competitiveness between what were effectively two arms of the state planning apparatus -the local authority and the DDDA - generated by the perceived potential of the market and development value of the area is a clear outcome of entrepreneurial approaches to urban governance. Perhaps this drive to 'win out' drove the DDDA to invest more than $€ 30$ million in the joint venture as part of the Becbay consortium. The contradictions of the DDDA simultaneously operating as developer and planning regulator had been raised by politicians and some journalists two years before the collapse: 
Is it really the business of a State development agency to be getting involved in such a massively leveraged project? What it brings to the party is the statutory power to have the developments exempted from planning, which was granted to it by the Government in order to expedite its mandate to redevelop Dublin's docks. A fair question is: what will happen if the project runs into difficulties and McNamara's solution is a material change to the current proposal, such as adding a few extra floors to the apartment blocks and scrapping the affordable housing? The DDDA will then find itself in the position of either waving goodbye to the taxpayers $€ 32.17$ million or going along with something that is potentially contrary to its own mandate. (McManus, The Irish Times, December 4, 2006).

Although the DDDA equity contribution was $€ 32.17$ million, their total liability on the site was in the order of $€ 123$ million following site works. While the relevant central government Minister was made aware of negotiations in relation to the purchase of the site, the Department of the Environment received rapidly changing and escalating valuations up until the closure of the deal. Even though the Executive of the DDDA advised their Board that the joint venture would happen in an "over-heated commercial property market" the bid went ahead (Comptroller and AuditorGeneral, 2012). The DDDA also guaranteed the repayment of all loans, including those of the private developer, by the consortium. Once the financial crisis hit in 2008, all parties including the lender - Anglo Irish Bank - became bankrupt, leaving the state with a significant exposure. The National Asset Management Agency (the state's bad bank) took over the loans of the consortium and, in January 2011, called in the guarantee from the DDDA. Given the inability of one state agency (DDDA) to pay another (NAMA), the assets of the docklands Authority worth a mere $€ 7.8$ million were transferred to NAMA in return for extinguishing the guarantee. In less than a decade, this one site had moved from quasi-public ownership in the Dublin Port Company to public-private venture as part of the Becbay consortium and later was effectively nationalized at massive cost to the tax-payer.

\section{Unpacking institutional vulnerabilities and charting a new future}

While initially conceived in policy terms in the late 1990s as a 'macro-actor' facilitating and coordinating development between a range of actors, by the early 2000's the DDDA was almost entirely dominated by closely-aligned private sector interests operating within a culture of risktaking and more traditional and cautious approaches to development had been entirely sidelined. 
In the context of an economic boom where the discourses of entrepreneurialism and competition permeated all decision-making, a very small group of private-sector individuals became significant players in the evolution of the docklands project both through their influence as major property owners but also through their ability to exert control within the development agency. In essence the so-called quasi-state agency became an instrument of the private-sector facilitated by the autonomous and flexible manner in which it had been established without proper governance structures. Previous property development successes in areas like the Grand Canal Dock and the generation of significant revenue through land sales and development for the central exchequer 'justified' the lack of oversight and contributed to a heightened liberalisation and marketisation in its approach to regeneration. One investigation into the operation of the DDDDA stated that:

"it appears that the Authority's planning functions were generally subservient to its development and architectural functions and that planning was used to promote development. This philosophy seriously compromised the integrity of the planning function" (Submission of Corporate Governance, Financial and Planning Reviews to the Minister for the Environment, Heritage and Local Government Report of the Executive Board of the Dublin Docklands Development Authority, May 2010).

Another report noted that:

"The planning function appears to have operated to some extent in a facilitating or enabling role rather than regulatory role with the evidence suggesting that the adjudicative process appears on the face of the Planning Reports at least to have been liberally and inconsistently interpreted with the effect, whether intended or not, of 'shoehorning' proposals into compliance with the Planning Scheme" (Brassil, 2010, p. 75)

Of the eight board members directing the Authority in 2005, six were private sector representatives including property developers and financiers, one represented central government and the Chair, a political appointee, was a board member of the bank that had lent the money for the purchase of the Irish Glass Bottle site. An investigation by the Comptroller and Auditor General suggested that the 'state agency' had become "composed primarily of persons who had no qualifications or experience as planners, architects, engineers or associated design/property/construction professionals" (Brassil, 2010). The composition of the Board of the Dublin Docklands Development Authority -appointed by the Minister for the Environmentprovides clear evidence of the manner in which "actually existing neoliberalism" (Brenner and 
Theodore, 2002) was produced and facilitated by central government and ultimately created the conditions through which the triple crisis was materially grounded in Dublin

"There has been a 'light touch' approach by the Department of Environment, Heritage and Local Government with respect to the DDDA both in relation to its wider sponsorship of the Authority and its planning responsibilities. There is a greater need now for the Department to have a more 'hands on' strategic management role." (Brassil, 2010, p. 35).

These reports and the example of the IGB site clearly highlight the role of weakened regulation and increased privatisation in the major failures of governance and planning in Dublin Docklands and the increased intersectionality between state agencies and private sector interests and agendas. It clearly illustrates how the "local institutional context clearly (and really) matters in the style, substance, origins and outcomes..." of neoliberalising processes (Peck, 2004, p 395) but also highlights how a particular - neoliberalising- approach became appropriated across the range of actors and institutions that constituted the growth coalition revalorizing the docklands. Ironically, the competitive tensions between various public authorities -Dublin City Council as local authority and the Dublin Docklands Development Authority as development agencybecause of their desire to shape a new world-class city quarter and attract private sector investment, facilitated hyper-entrepreneurial behaviour. Ultimately this required state intervention in the form of the nationalization of a very large and strategic development site and generated a catastrophic collapse in land values, contrary to the collective interests of promoting urban growth. Of most interest though was the discourse created around the governance failures of the DDDA, once its abolition was announced, without any consideration being given to the legitimacy of the overall approach to planning and development. While this would seem to provide some evidence to support what Ward (2007) refers to as a post-political urban condition based on the inevitability of neoliberal capitalism or the normalization of neoliberal governmentalities as suggested by Keil (2009), in the Irish case study the policies and practices of the DDDA have not in fact been legitimised but separated, discursively constructed as anomalous, from the general context within which they were operating. In 2012, a new DDDA Board was appointed, comprised primarily of public sector representatives, to wind up the operations of the authority. In March 2016, Dublin City Council reacquired control of and responsibility for the docklands area. 


\subsection{A post-crisis growth machine? 2016 to date}

Following the re-integration of the Dublin Docklands under the remit of Dublin City Council, a dedicated internal unit was established to ensure a continued focus on regeneration in this part of the city, and specifically in an area of the north and south docks designated in 2012 as a fasttrack planning, Strategic Development Zone (SDZ). Although the institutions and particular set of actors at work in, and regulating, this particular part of the city were substantially changed, the overall growth logic and rationalities remained the same and arguably intensified along new trajectories.

NAMA - the state bad bank - emerged as a significant and strategic player across the north docklands through its control of distressed financial assets linked to real estate, and its operational activities transitioned from being focused on asset resolution to one of land management and development. This new institution represented another form of state intervention readjusting and working through the outcomes of a previous crisis and supporting a new form of neoliberal urbanism through financialization (Byrne, 2016). Many of the development portfolios it controlled have now been sold to private equity firms and NAMA were centrally involved in discussions creating the designation of the North Lotts as an SDZ. The planning scheme was approved in May 2014 and divided the bounded area into 20 development blocks. NAMA originally held an interest in 15 of the 20 blocks and actively developed detailed strategies for each of them. At one point, they controlled an interest in $75 \%$ of the 22 ha of development land within the SDZ boundary making them a key player in both working through contradictions of previous approaches but also in creating new tools of commodification to sustain the overall development trajectory. At Capital Dock in the south docklands, they entered into a joint venture with international development firm, Kennedy Wilson. The role of NAMA -albeit a new institution - in sustaining the docklands growth machine was articulated by the Chief Executive, Brendan McDonagh, in a press release related to another strategic block on North Wall Quay in the north docks: "This transaction with Oxley will facilitate the provision of much-needed high-quality Grade A office space that will lead to further job creation, investment and economic activity in the Dublin Docklands, while maximising the value of this site for NAMA". NAMA have retained a freehold interest in this site to ensure a long term income stream highlighting the role of both the public and private sectors, working separately and in collaboration, to maximise the exchange value of urban land. Most of this part of docklands has now been built out. 
Based on the perceived success of this first SDZ, the Poolbeg West area including the Irish Glass Bottle site received SDZ designation in 2016. Dublin City Council are named as the relevant 'development agency' for the site and the 34 hectares have been marketed as "of economic and social importance to the state". A brownfield and former industrial site, one can surmise that the 'importance' is primarily related to recouping some of the earlier losses on the back of the Becbay consortium debacle. In mid-2019, NAMA who control the 15ha site launched a call for bidders to acquire an $80 \%$ share in the site and develop 3,500 apartments, 930,000sq.m. of commercial development, as well as a school, community and public open spaces. The state will retain a 20\% interest in the site as a long-term investment strategy indicative of the deeply embedded neoliberal governmentalities that conceptualise urban spaces primarily as sites for value extraction and potentially sowing the seed for future potential tensions when this value extraction activity often undertaken in the name of the 'common good' collides with wider social imperatives. These tensions are also evident across docklands as the Smart Docklands initiative is rolled out as another element of neoliberal restructuring (Kayanan et al., 2018) and the use of urban space becomes commodified through test-bedding new sensors and technologies. The implications of this for urban social justice, inclusion and future development are significant but beyond the scope of this paper.

\section{Conclusion}

Dublin Docklands today has become a cornerstone of the urban fabric and economy of Dublin and Ireland, representing for many a new urban quarter and a model to emulate. It embodies the rapid restructuring that has been experienced in Ireland over the last thirty years. Each of the phases of regeneration outlined above, illustrate how global flows of capital and investment interplay with local contexts -economic, social and institutional- to produce outcomes that are both intended and often unintended. It is through these unintended consequences of regeneration that particular, albeit changing, vulnerabilities are reinforced or produced often down to the nature and extent of state intervention. This paper has illustrated with reference to Dublin Docklands that the 'competitiveness' agenda and neoliberal approaches to urban development since the late 1980s, has effectively complicated rather than 'streamlined' urban regeneration and produced new weaknesses. Though large tracts of Dublin docklands have been transformed from derelict and economically/socially depressed urban environments into vibrant and economically successful urban districts, this has been fraught with conflict and competing visions. Over time, the nature of vulnerability has shifted but many would argue the structural 
underpinnings have remained remarkably resilient. Many of those communities who were among the most vulnerable in the 1980s at high-risk for unemployment, poor health and poorer social outcomes remain disadvantaged.

The recent Covid-19 pandemic represents a new threat and the trajectory of development within docklands may render it particularly exposed to the anticipated impacts. The fate of some of the new commercial developments in the area is uncertain given the likelihood of a property market dip, and the nature of economic activity in the area may be particular vulnerable. For example, Dublin Docklands is the home to the international aviation leasing sector with more than $70 \%$ of all global aviation leasing being managed from the south docks. The deepening global interconnectedness and availability of mobile global capital that has driven much of the regeneration to date may be significantly diminished. From the perspective of urban form, while emerging evidence suggests that higher density is not necessarily linked to higher risk in terms of contracting the virus, higher levels of connectivity particularly within large metropolitan areas seem to be a significant risk factor (Hamidi et al., 2020). The mantra of docklands being one of the most connected neighbourhoods in Europe may yet prove problematic both materially and discursively. Within the context of the pandemic lockdown, the comparatively poorer quality urban environment - devoid of greenspace and street trees- became particularly challenging both in terms of quality of life but also with potentially significant mental health implications (Callaghan et al., 2020). The consequences of decades of intervention focused on extracting the maximum exchange value from particular development sites and the sustained promotion of growth-first logics, even after the global financial crisis, have been throw into sharp relief as a result of the Covid-19 pandemic.

Dublin Docklands is a space that has been discursively constructed over many decades through the interplay between global, national and local; public/private; fixed and mobile capital that has been enabled through roll-back, roll-out and roll with it forms of neoliberalisation (Keil, 2009). Even under extreme challenge after the global financial crisis, the forms of 'austerity urbanism' pursued in Dublin Docklands have more deeply embedded particular governmentalities and produced new and changing vulnerabilities. This case study represents a microcosm of the rapid economic, physical and social changes in Ireland since the late 1980s. The docklands is a place that represents narrowly defined forms of success but also embodies significant challenges related to urban governance, activism, social and environmental justice that state intervention attempts to mitigate but often (un-) intentionally co-produces. 
Acknowledgements: With thanks to the two anonymous referees for their valuable comments on an earlier draft of the paper.

Authorship statement: The author declares no conflict of interest. I can confirm that I am the sole author of this paper and that the conception, data collection, and writing of the paper are my own work. 


\section{References}

Aalbers, M. B. (2020). Financial geography III: The financialization of the city. Progress in Human Geography, 44(3), 595-607. https://doi.org/10.1177/0309132519853922

Bannon, M. (1989). Planning: the Irish experience, 1920-1988. Dublin: Wolfhound Press.

Benson, F. (1988). The Custom House Docks. In J. Blackwell \& F. Convery (Eds.), Revitalizing Dublin: What works? (pp. 90-98). Dublin: REPC.

Brenner, N. (2004). New state spaces: Urban governance and the rescaling of statehood. Oxford University Press.

Brenner, N., \& Theodore, N. (2005). Neoliberalism and the urban condition. City, 9(1), 101107. https://doi.org/10.1080/13604810500092106

Brownill, S., \& Carpenter, J. (2009). Governance and Integrated Planning: The Case of Sustainable Communities in the Thames Gateway, England. Urban Studies, 46(2), 251274. https://doi.org/10.1177/0042098008099354

Brownill, S. (1990). Developing London's Docklands: another great planning disaster? London: SAGE.

Byrne, M. (2016). Entrepreneurial Urbanism After the Crisis: Ireland's "Bad Bank" and the Redevelopment of Dublin's Docklands. Antipode, 48(4), 899918. https://doi.org/10.1111/anti.12231

Callaghan, A., McCombe, G., Harrold, A., McMeel, C., Mills, G., Moore-Cherry, N., \& Cullen, $W$. (2020). The impact of green spaces on mental health in urban settings: a scoping review, Journal of Mental Health. hittps://doi.org/10.1080/09638237.2020.1755027

Connor, D., Mills, G., \& Moore-Cherry, N. (2011). The 1911 Census and Dublin city: A spatial analysis. Irish Geography, 44(2-3), 245-263

Crouch, C., \& Le Galès, P. (2012). Cities as national champions? Journal of European Public Policy, 19(3), 405-419. https://doi.org/10.1080/13501763.2011.640795

Cox, K. (2010). The problem of metropolitan governance and the politics of scale. Regional Studies, 44(2), 215-227. https://doi.org/10.1080/00343400903365128

Davies, J. S. (2002). The governance of urban regeneration: a critique of the 'governing without government' thesis. Public administration, 80(2), 301-322. 
Duffy, K., \& Hutchinson, J. (1997). Urban policy and the turn to community. Town Planning Review, 68(3), 347-362.

Fuller, C., \& Geddes, M. (2008). Urban governance under neoliberalism: New Labour and the restructuring of state-space. Antipode, 40(2), 252-282.

Hamidi, S., Sabouri, S., \& Ewing, R. (2020). Does Density Aggravate the COVID-19 Pandemic? Early Findings and Lessons for Planners. Journal of the American Planning Association, 86(4), 115. https://doi.org/10.1080/01944363.2020.1777891

Henderson, S. (2012). An evaluation of the layering and legacy of area-based regeneration initiatives in England: the case of Wolverhampton. Urban Studies, 49(6), 1201 1227. https://doi.org/10.1177/0042098011415432

Jessop, B. (1997). The Entrepreneurial City. In N. Jewson, \& S. MacGregor (Eds.), Transforming Cities: Contested Governance and New Spatial Divisions. London: Routledge.

Jessop, B. (1998). The enterprise of narrative and the narrative of enterprise: place marketing and the entrepreneurial city. In T. Hall \& P. Hubbard (Eds.), The Entrepreneurial City (pp. 77-99). Chichester: Wiley.

Jessop, B. (1990). State theory: Putting the capitalist state in its place. University Park: Penn State Press.

Jones, M., \& Ward, K. (2002). Excavating the logic of British urban policy: Neoliberalism as the "crisis of crisis-management". Antipode, 34(3), 473-494.

Jones, P., \& Evans, J. (2006). Urban regeneration, governance and the state: Exploring notions of distance and uroximity. 1491 1509. https://doi.org/10.1080/00420980600749951

Kayanan, C. M., Eichenmüller, C., \& Chambers, J. (2018) 'Silicon slipways and slippery slopes: techno-rationality and the reinvigoration of neoliberal logics in the Dublin Docklands'. Space and Polity, 22(1), 50-66. https://doi.org/10.1080/13562576.2018.1488556

Keil, R. (2009). The urban politics of roll-with-it neoliberalization. City, 13(2-3), 230245. https://doi.org/10.1080/13604810902986848

Kitchin, R., O'Callaghan, C., Boyle, M., Gleeson, J., \& Keaveney, K. (2012). Placing neoliberalism: the rise and fall of Ireland's Celtic Tiger. Environment and Planning A, 44(6), $1302-$ 1326. https://doi.org/10.1068/a44349 
Lowndes, V., Nanton, P., McCabe, A., \& Skelcher, C. (1997). Networks, partnerships and urban regeneration. Local Economy, 11(4), 333-342.

Medd, W., \& Marvin, S. (2005). From the politics of urgency to the governance of preparedness: A research agenda on urban vulnerability. Journal of contingencies and crisis Management, 13(2), 44-49.

Molotch, H. (1976). The city as a growth machine: Toward a political economy of place. American Journal of Sociology, 82(2), 309-332

Moore-Cherry, N., \& Vinci, I. (2012). Urban regeneration and economic crisis: past development and future challenges in Dublin, Ireland. PLANUM, The Journal of Urbanism, 25(2), 1-16.

Moore-Cherry, N., Crossa, V., \& O’Donnell, G. (2015). Investigating urban transformations: GIS, map-elicitation and the role of the state in regeneration. Urban Studies, 52(12), 21342150. https://doi.org/10.1177/0042098014545520

Moore-Cherry, N. (2015). 'Re-thinking the post-crash city: vacant space, temporary use and new urban imaginaries?' Irish Geography, 48(1), 6-12. https://doi.org/10.2014/igj.v48i1.523

Moore, N. (1999). Rejuvenating docklands: the Irish context. Irish Geography, 32(2), 135-149.

Moore, N. (2002). From indigenous industry to foreign finance: the changing face of Dublin Docklands. Land Use Policy, 19(4), 325-331.

Moore, N. (2008). Dublin docklands reinvented: the post-industrial regeneration of a European city quarter. Dublin: Four Courts Press.

O'Brien, P., Pike, A., \& Tomaney, J. (2019). Governing the 'ungovernable'? Financialisation and the governance of transport infrastructure in the London 'global city-region'. Progress in Planning, 132, 100422. https://doi.org/10.1016/j.progress.2018.02.001

O'Callaghan, C., Kelly, S., Boyle, M., \& Kitchin, R. (2015). Topologies and topographies of Ireland's neoliberal crisis. Space and Polity, 19(1), 46. https://doi.org/10.1080/13562576.2014.991120

Osborne, S. (2002) Public management: The plural state. London: Routledge.

Painter, J., \& Jeffrey, A. (2009). Political geography. London: Sage.

Peck, J. (2004). Geography and public policy: constructions of neoliberalism. Progress in human geography, 28(3), 392-405. http://doi.org/10.1191/0309132504ph492pr 
Peck, J. (2012). Austerity urbanism: American cities under extreme economy. City, 16(6), 626655. https://doi.org/10.1080/13604813.2012.734071

Ponzini, D., \& Rossi, U. (2010). Becoming a creative city: The entrepreneurial mayor, network politics and the promise of an urban renaissance. Urban studies, 47(5), 1037 1057. https://doi.org/10.1177/0042098009353073

Smith, N. (1990). Uneven Development: Nature, Capital and the Production of Space. Oxford: Blackwell, 2nd edition.

Swyngedouw, E., Moulaert, F., \& Rodriguez, A. (2002). Neoliberal urbanization in Europe: large-scale urban development projects and the new urban policy. Antipode, 34(3), 542-577.

Telesis Consultancy Group (1982). A review of industrial policy: a report prepared by the Telesis Consultancy Group. Dublin: National Economic and Social Council reports, no. 64.

Tewdwr-Jones, M. (2012). Spatial planning and governance: Understanding UK planning. London: Macmillan International Higher Education.

Thornley, A. (1991). Urban Planning under Thatcherism: The Challenge of the Market, London: Routledge.

Ward, K. (2003). Entrepreneurial urbanism, state restructuring and civilizing 'New' East Manchester. Area, 35(2), 116-127.

Ward, K. (2007). "Creating a personality for downtown": Business Improvement Districts in Milwaukee. Urban Geography, 28(8), 781-808. https://doi.org/10.2747/0272-3638.28.8.781 Whelan, K. (2014). Ireland's economic crisis: The good, the bad and the ugly. Journal of Macroeconomics, 39, 424-440. https://doi.org/10.1016/j.jmacro.2013.08.008 